\title{
Utilization of Phosphoric Acid and Lime for Stabilizing Laterite for Lateritic Bricks Production
}

\author{
Adekoya, A.D. ${ }^{1}$, Ayodele, A.L. ${ }^{*}$, Fajobi, A.B. ${ }^{1}$, Oluwatosin, A. ${ }^{1}$, Mohammed, A.O ${ }^{1}$, and Itedjere, O.A. ${ }^{1}$
}

\begin{abstract}
The use of innovative technologies in building construction using locally available materials can lead to affordable housing and boost the socio-economic development of a nation. Laterite soils were stabilized with varying percentages $(0,2,4$ and $6 \%)$ of $1 \mathrm{M}$ phosphoric acid $\left(\mathrm{H}_{3} \mathrm{PO}_{4}\right)$ and $5 \%$ lime to ascertain its suitability as sustainable material for hollow lateritic bricks production. The bricks were cured for 7, 14 and 28 days under ambient air condition. The compressive strength $\left(f_{c}\right)$, bulk density $\left(p_{b}\right)$, dry density $\left(p_{d}\right)$, modulus of rupture $\left(f_{r}\right)$. The results were a maximum $f_{c}$ of 0.93 and $0.87 \mathrm{~N} / \mathrm{mm}^{2}$ at $5 \%$ lime and $4 \% \mathrm{H}_{3} \mathrm{PO}_{4}$. Maximum $p_{b}$ and $p_{d}$ of 15.2 and $14.9 \mathrm{kN} / \mathrm{m}^{3}$, respectively were obtained at $4 \% \mathrm{H}_{3} \mathrm{PO}_{4}$ stabilization. Maximum $f r$ of $0.2 \mathrm{~N} / \mathrm{mm}^{2}$ was obtained at combined $4 \% \mathrm{H}_{3} \mathrm{PO}_{4}$ and $5 \%$ lime. In conclusion, the $f_{\mathrm{c}}$ suggests that both lime and $\mathrm{H}_{3} \mathrm{PO}_{4}$ have great potential in stabilizing laterite soils.
\end{abstract}

Keywords: Phosphoric acid; lateritic bricks; hydrated lime; compressive strength; modulus of rupture; dry density; $\mathrm{pH}$.

\section{Introduction}

Bricks made from plain soils for centuries have been used in building mud house [1]. The most consistent of these soil types are laterites. Laterite soils which are highly weathered tropical and subtropical residual soils are old and popular construction material that has served humanity for centuries now.

In Nigeria and other tropical regions, lateritic soils are common and are used in construction such as production of bricks, sub base for road pavement among others. Heavy rainfall and elevated or warm temperature which are characteristics of tropical and subtropical regions, makes rock weathering intensive. This usually results in the rapid breakdown of feldspars and ferromagnesian minerals, the removal of silica and bases $\left(\mathrm{Na}_{2} \mathrm{O}, \mathrm{K}_{2} \mathrm{O}, \mathrm{MgO}\right)$ [2], and the concentration of iron and aluminum oxides [3]. This process of breakdown of feldspars and removal of silica is termed laterization [4] which also involves the leaching of $\mathrm{SiO}_{2}$ and deposition of $\mathrm{Fe}_{2} \mathrm{O}_{3}$ and $\mathrm{Al}_{2} \mathrm{O}_{3}$.

Laterites, when used in making bricks, such bricks are called lateritic bricks and they have many attractive features, some of which are locally available and cheap materials, bricks of good esthetics and recyclability.

${ }^{1}$ Department of Civil Engineering, Obafemi Awolowo University, NIGERIA.

*Corresponding author; Email: layodele@ oauife.edu.ng

Note: Discussion is expected before July, 1st 2021, and will be published in the "Civil Engineering Dimension", volume 23, number 2, September 2021.

Received 22 May 2020; revised 23 December 2020; accepted 03 January 2021
However, there can be a severe structural failure if the bricks are not properly strengthened, hence the need and emphasis for stabilization [5]. Soil stabilization is the process of improving the physical and engineering properties of a soil to obtain some predetermined targets [6]. Among the various soil improvement methods (mechanical, and chemical stabilization), the use of chemicals, (especially lime and cement) for soil stabilization to increase soil strength and to reduce settlement/compressibility, seems to be a more popular choice, probably because of its convenience.

Lime stabilization, as one of the commonest processes of improving the engineering properties of soils chemically, has been used extensively in the past and recently [2,7-9], . Lime is particularly suitable for fine grained soils. The reactions between lime and clay minerals present in soil will result in changes in the plasticity properties and soil structure; therefore, higher load capacity and mechanical resistance are induced [9]. The addition of excessive lime is not desirable, as it can lead to strength reduction, especially for silica rich soil. The reduction in strength can be attributable to excessive formation of silica gel, a highly porous material [9]. Thus, the amount of lime can vary from 5 to $12 \%$ by weight of the soil.

There has been a proliferation of literature regarding the application of non-calcium-based stabilizers, such as coconut husk ash [10], natural rubber latex [11], recycled sugarcane fiber waste [12], sawdust and egg shell ash [13], for soil stabilization. This is to replace cement, especially because its production has been associated with the depletion of nature's non- 
renewable resources, consumption of substantial energy and contribution to carbon dioxide emission into the atmosphere [5]. Phosphoric acid $\left(\mathrm{H}_{3} \mathrm{PO}_{4}\right)$, which is a mineral acid, non-toxic, that poses no threat to the environment, has been shown to be one of the alternative stabilizers especially for laterite soils [6,14-16]. As stated earlier, lateritic soil is highly weathered natural material formed by the concentration of hydrated oxides of iron and aluminium [4]. Phosphoric acid can effectively leach out alumina and other metallic oxides from clay minerals [6]. Thus, phosphate from phosphoric acid, can react with free iron and aluminum oxides present in the lateritic soil environment to form cementitious, highly insoluble aluminium and iron phosphate compounds such as strengite $\left(\mathrm{AlPO}_{4} .2 \mathrm{H}_{2} \mathrm{O}\right)$, variscite $\left(\mathrm{FePO}_{4} .2 \mathrm{H}_{2} \mathrm{O}\right)$ among others [17]. A typical reaction between phosphate with soil mineral is presented in Equation 1.

$\mathrm{Al}^{3+}+2 \mathrm{OH}^{-}+\mathrm{H}_{2} \mathrm{PO}_{4}^{-}+\mathrm{xH}_{2} \mathrm{O} \rightarrow$ $\mathrm{Al}(\mathrm{OH})_{2} \mathrm{H}_{2} \mathrm{PO}_{4} \cdot \mathrm{xH}_{2} \mathrm{O}$

The product $\mathrm{AI}(\mathrm{OH})_{2} \mathrm{H}_{2} \mathrm{PO}_{4}$ is hard and highly insoluble. A similar reaction exists between $\mathrm{Fe}_{2} \mathrm{O}_{3}$ (goethite), and the phosphate source. The product is $\mathrm{Fe}(\mathrm{OH})_{2} \cdot \mathrm{H}_{2} \mathrm{PO}_{4} \cdot \mathrm{xH}_{2} \mathrm{O}$, which is also hard and highly insoluble. It has, however, been shown that these compounds can be formed in an acidic environment $[6,15,16]$, fortunately, laterite and lateritic soils are acidic in nature [4]. Phosphate can also be precipitated in highly alkaline environment by calcium. According to Rooselers and Van Loosdrecht [18], the most stable calcium salt is calcium phosphate which is formed as presented in Equation 2.

$5 \mathrm{Ca}^{2+}+3 \mathrm{PO}_{4}^{3-}+\mathrm{OH}^{-} \rightarrow \mathrm{Ca}_{5}\left(\mathrm{PO}_{4}\right)_{3} \mathrm{OH}_{(\mathrm{s})}$

Thus, if the $\mathrm{pH}$ of laterite soil can be increased in the presence of calcium and phosphate, cementitious compound of calcium phosphate could be formed. Baldovino et al. [9] stated that the addition of lime can cause a sudden increase in soil $\mathrm{pH}$ value due to the partial dissolution of calcium hydroxide $\mathrm{Ca}(\mathrm{OH})_{2}$.

This research was, therefore, carried out to investigate the efficacy of the combination of lime and phosphoric acid on the stabilization of a laterite soil and to possibly ascertain the mix proportion required to produce durable and sustainable lateritic bricks.

\section{Materials and Method}

\section{Materials}

The following materials were used for this work: A suitable lateritic soil collected at the borrow pit opposite Oduduwa University, Ile-Ife, Nigeria. The lateritic soil was primarily identified by its physical characteristics (reddish colour, sticky texture).
The longitude and latitude of the location from which the laterite was collected is $7^{\circ} 29^{\prime} 52.812$ " $\mathrm{N}$, $4^{\circ} 26^{\prime} 57.546^{\prime \prime}$ E.

Phosphoric acid, also known as orthophosphoric acid $\left(\mathrm{H}_{3} \mathrm{PO}_{4}\right)$, was prepared to a molarity of $1 \mathrm{~mol} / \mathrm{dm}^{3}$ by dilution with distilled water. Lime (hydrated) was purchased from a dealer. It is recommended that potable water, i.e water safe for human consumption, should be used for batching. Pipe borne water hence was used for batching.

\section{Method}

\section{Determination of the Physical Properties of Lateritic Soil}

Some geotechnical properties such as specific gravity, Atterberg's limits (Liquid limit, plastic limit and plasticity index), particle size distribution and compaction properties of the laterite soil were determined. The Atterberg's limits and particle size distribution results were used for the classification of the soil.

\section{Stabilization of Lateritic Soil for Brick Produc- tion}

For the evaluation of the physical properties of lateritic bricks, the lateritic soil was sieved with a sieving machine with a $2 \mathrm{~mm}$ aperture. The bricks were produced in batches per stabilizer variable. Various percentages of $\mathrm{H}_{3} \mathrm{PO}_{4}$ up to $6 \%$ at $2 \%$ interval, $5 \%$ lime and a combination of $\mathrm{H}_{3} \mathrm{PO}_{4}$ and lime in their respective percentages, resulting in 7 stabilizer variables and 1 unstabilized control brick. The mixing was done using a mixing machine. These variations were made in order to evaluate how the proportions of the chemicals affect the brick's physical properties. The bricks were produced using a hydraulic brick making machine of mold size $300 \mathrm{~mm}$ x 150 $\mathrm{mm} \times 80 \mathrm{~mm}$ as shown in Figure 1.

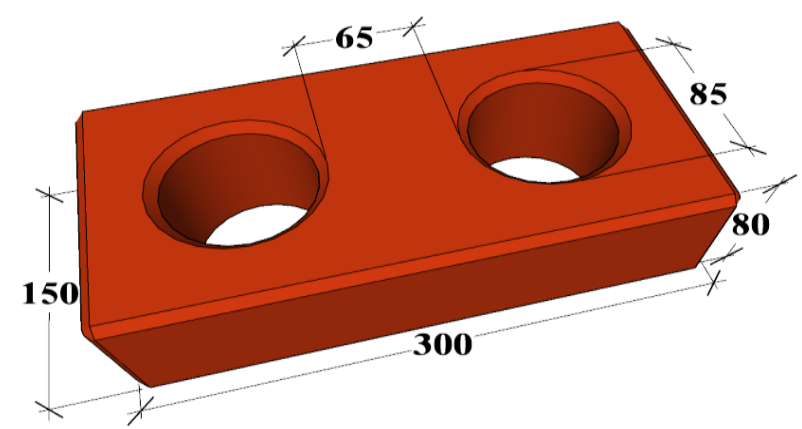

Figure 1. Brick with Dimensions (all dimensions in $\mathrm{mm}$ )

\section{Determination of Physical Properties of the Stabilized Bricks}

Physical properties such as bulk density. dry density, water absorption, compressive strength, $\mathrm{pH}$ and modulus of rupture of the bricks were determined. 
Both bulk and dry density of lateritic bricks are important parameters, by which bricks may be specified [5] and they simply indicate the bulk and dry mass of the brick per unit volume, respectively. The mass and volume of the bricks after curing were measured. The bulk density was determined by dividing the mass by volume. The volume is determined by mathematically calculating the volume of the shape dimensions of the brick.

A portion of the brick was obtained after crushing and oven dried to determine the water content. The dry density of the brick was determined using Equation 3.

$\rho d=\frac{\rho b}{1+\omega}$

Where: $\rho d=$ brick dry density, $\rho b=$ brick's bulk density, $\mathrm{w}=$ water content.

Water absorption tests on bricks are conducted to determine durability property of bricks such as degree of burning, quality and behavior of bricks in weathering. The degree of compactness of bricks can be obtained by water absorption test, as water is absorbed by pores in bricks. The specimen was airdried and its weight obtained. The specimen was completely immersed in clean water at a temperature of $27 \pm 2^{\circ} \mathrm{C}$ for 24 hours. The specimen was removed and traces of water wiped with damp cloth and weighed after removal from water. The rate of water absorption of the bricks was then determined.

Compressive strength tests on bricks are carried out to determine the load carrying capacity of bricks under compression using compression testing machine. Whole bricks were taken and dimensions measured to the nearest $1 \mathrm{~mm}$. The specimen was placed with flat face horizontal and the load was applied at a uniform rate of $14 \mathrm{~N} / \mathrm{mm}^{2}\left(140 \mathrm{~kg} / \mathrm{cm}^{2}\right)$ per minute until failure occurs and the maximum load noted at failure. The load at failure is maximum load at which the specimen fails to produce any further increase in the indicator reading on the testing machine. The compressive strength of the brick specimens was determined.

The California Bearing Ratio (CBR) machine was used to determine the modulus of rupture $\left(f_{\mathrm{r}}\right)$ of the bricks in accordance with ASTM [19]. Each brick was placed over two supports with a clear distance of 274.6 $\mathrm{mm}$ between the supports. The distance between the end of the brick and each support was $12.7 \mathrm{~mm}$. A plain steel bar was placed at the center of the brick to serve as point liner load and the plunger of the CBR machine was lowered down until it touched the bar before the machine was switched on. The load was applied at a loading rate of $50 \mathrm{kN}$ and the load at which each brick failed in flexure was recorded along with the distance from the mid span to the plane of failure. The procedure was repeated for other brick samples. Two samples were tested for each stabilizer variation and the average result calculated, Equation 4 gives the necessary applied parameters.

The modulus of rupture $\left(f_{r}\right)$ is calculated using Equation 4.

$\mathrm{f}_{r}=\frac{3 F(0.5 L-x)}{b d^{2}}\left(\mathrm{~N} / \mathrm{mm}^{2}\right)$

Where: $\mathrm{F}=\mathrm{Load}$ at failure $(\mathrm{N}) ; \mathrm{L}=$ length of brick $(\mathrm{mm}) ; \mathrm{x}=$ Distance from the plane of fracture to the midpoint of the brick $(\mathrm{mm}) ; \mathrm{d}=$ Net width of the sample less hole $(\mathrm{mm})$ and $\mathrm{b}=$ Depth of the sample $(\mathrm{mm})$.

\section{Results and Discussion}

\section{Physical Properties and Classification of Lateritic Soil}

The physical properties and classification of the lateritic soil are presented in Table 1. The Atterberg's limits, i.e Liquid limit (LL), Plastic limit (PL) and Plasticity index (PI)) of the natural soil sample are $51.35 \%, 39.26 \%$, and $12.09 \%$, respectively. The PI of the soil suggests that the soil is of medium plasticity. According to Das [20], soils with PI ranging from 1 to 5 are described as slightly plastic, soils with PI ranging from 5 to 10 are described as low plasticity and soils with PI ranging from 10 to 20 are described as medium plasticity.

Table 1. Results of Preliminary Tests

\begin{tabular}{ll}
\hline Properties & Result \\
\hline Natural moisture content (\%) & 28.54 \\
Specific gravity & 2.82 \\
pH & 6.2 \\
Liquid limit (\%) & 51.35 \\
lastic limit (\%) & 39.26 \\
Plasticity index (\%) & 12.09 \\
Percent of sand (\%) & 48.32 \\
Percent of silt and clay (\%) & 51.68 \\
Soil classification (USCS) & MH (High plasticity silt) \\
Soil classification (AASHTO) & A-7-5 (Clayey soil) \\
Optimum moisture content (\%) & 17.30 \\
Maximum dry density (g/cm ${ }^{3}$ ) & 1.57
\end{tabular}

The selected lateritic soil sample was classified according to AASHTO [21] and USCS [22] classification systems using Atterberg's limits and particle size distribution results. The particle size distribution results show that the percentage of soil passing sieve No. 200 is 51.68 (>36 $\mathrm{min}$ ), hence the soil falls within the Silt-Clay materials. LL is $51.35 \%$ and PI is $12.09 \%$, hence the soil falls in (A-7, A-7-5a, A-7-6b) group, but PI $\leq$ LL-30, therefore soil is A-7-5. In 
addition to this, using USCS, more than 50\% of soil sample passed sieve No. 200, which implies the soil is fine grained. Liquid limit is more than 50 and according to the USCS the soil is silt or clay. From the plasticity chart and considering the LL and PI the plot is below the " $\mathrm{A}$ " line, therefore soil is MH (High plasticity silt).

\section{Effect of Phosphoric Acid and Lime on the Bulk and Dry Density of Stabilized Lateritic Brick}

The results of the bulk and dry density for the bricks produced from laterite stabilized with different percentages of $\mathrm{H}_{3} \mathrm{PO}_{4}$ and lime after 7, 14, and 28 days curing are shown in Figures 2 and 3. It has been shown by Fadele and Ata [5] that density is part of the properties by which bricks may be specified. Bricks with density exceeding $1000 \mathrm{~kg} / \mathrm{m}^{3}\left(9.81 \mathrm{kN} / \mathrm{m}^{3}\right)$ may be classified as high density (HD) bricks. The values of the densities presented in Figures 2 and 3 indicate that the bricks are HD bricks. The values of density obtained in this study is slightly lower than that obtained by Fadele and Ata [5], this could be due to the method of compaction used. It was observed that there was a decrease in bulk density with the passage of time; this is largely due to the loss of moisture through the air-drying process. The bulk density of the bricks stabilized with the combination of lime and $\mathrm{H}_{3} \mathrm{PO}_{4}$ decreased with increasing $\mathrm{H}_{3} \mathrm{PO}_{4}$ and $5 \%$ lime at the early stages of curing. The $4 \% \mathrm{H}_{3} \mathrm{PO}_{4}$ stabilized bricks gave the highest bulk and dry density of 15.2 $\mathrm{kN} / \mathrm{m}^{3}$ and $14.9 \mathrm{kN} / \mathrm{m}^{3}$ respectively after 28 days curing which was followed by $6 \% \mathrm{H}_{3} \mathrm{PO}_{4}$ stabilized bricks after 14 days curing. Under desirable conditions the optimum percentage of $4 \%$ diluted $\mathrm{H}_{3} \mathrm{PO}_{4}$ is optimum.

Statistical analysis of the results using 2-way Analysis of Variance (ANOVA) shows that neither the percentage of $\mathrm{H}_{3} \mathrm{PO}_{4}$ used nor the curing period had any significant effects on both the bulk and dry densities at $5 \%$ confidence level. However, with the addition of lime, the curing period $(p=0.035)$ had significant effect on both the dry and bulk densities with $\mathrm{p}<0.05$.

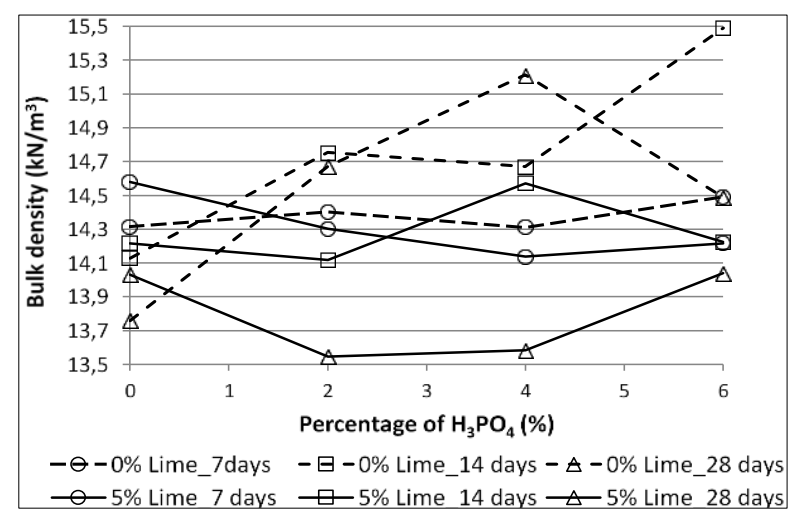

Figure 2. Bulk Density of Stabilized Lateritic Bricks

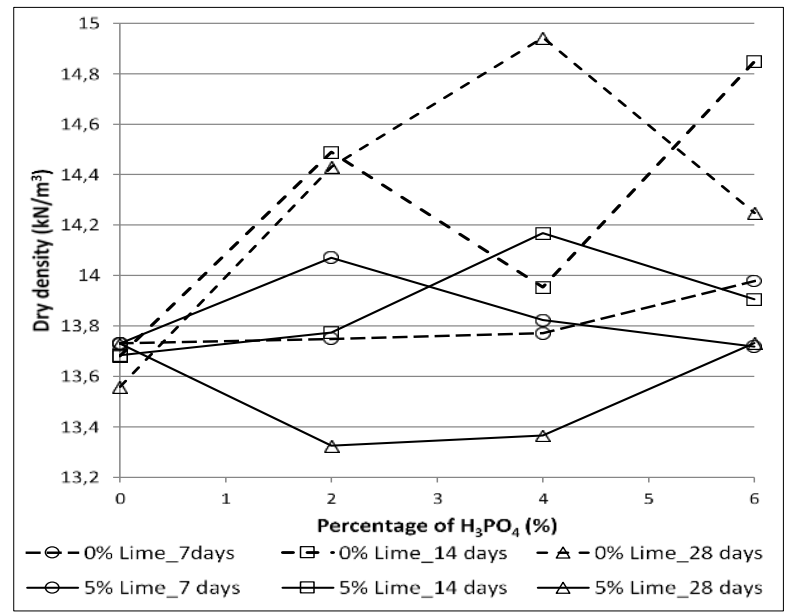

Figure 3. Dry Density of Stabilized Lateritic Bricks

Effects of Phosphoric Acid and Lime on the Compressive Strength of Stabilized Lateritic Brick

In order to determine the axial loading capacity of the bricks, the compressive test was used. The compressive strength of the bricks produced from laterite stabilized with variation of $\mathrm{H}_{3} \mathrm{PO}_{4}$ and lime after curing for 7, 14, and 28 days are presented in Figure 4. It shows that the compressive strength of the bricks increased with the increase in percentage of stabilization with lime and the combination of both lime and $\mathrm{H}_{3} \mathrm{PO}_{4}$. It was also observed that the compressive strength of the bricks increased with the curing age. According to ASTM [19], curing is important before testing to allow for considerable amount for cementation to take place. For bricks stabilized with only $\mathrm{H}_{3} \mathrm{PO}_{4}$ after 7 and 14 days, there was an increase in strength compared to the unstabilized control at $2 \%$ and $6 \%$. Only at $4 \%$ was a decrease observed at both the 7th and

14th day curing. However, after 28 days curing it possessed the highest compressive strength of the $\mathrm{H}_{3} \mathrm{PO}_{4}$ stabilized brick. It was only next to (in terms of strength) bricks stabilized with $5 \%$ lime and the combination of $5 \%$ lime and $6 \% \mathrm{H}_{3} \mathrm{PO}_{4}$.

For bricks stabilized with only $\mathrm{H}_{3} \mathrm{PO}_{4}$ after 7 and 14 days, there was an increase in strength compared to the unstabilized control at $2 \%$ and $6 \%$. Only at $4 \%$ was a decrease observed at both the 7 th and $14^{\text {th }}$ day curing. However, after 28 days curing it possessed the highest compressive strength of the $\mathrm{H}_{3} \mathrm{PO}_{4}$ stabilized bricks. It was only next to (in terms of strength) bricks stabilized with $5 \%$ lime and the combination of $5 \%$ lime and $6 \% \mathrm{H}_{3} \mathrm{PO}_{4}$. The results from Figure 2 shows that after 28 days curing, the maximum compressive strength of $0.87 \mathrm{~N} / \mathrm{mm}^{2}, 0.88 \mathrm{~N} / \mathrm{mm}^{2}$, and $0.93 \mathrm{~N} / \mathrm{mm}^{2}$ were obtained at $4 \%$ stabilization with $\mathrm{H}_{3} \mathrm{PO}_{4}$, combination of $5 \%$ and $6 \%$ stabilization with lime and 
$\mathrm{H}_{3} \mathrm{PO}_{4}$ and 5\% lime respectively. It has been shown by Sharma et al. in 2015 [23] that the compressive strength of bricks may increase up to the 28 days curing period and that the compressive strength at 56 days and 90 days curing period are the same with the 28 days curing period but are higher than the 7, 14, and 21-days curing period.

It was also observed that the $5 \%$ lime-stabilized bricks experience a slow and steady increase in strength within the 28 days of curing compared to the $2 \%$ and $6 \% \mathrm{H}_{3} \mathrm{PO}_{4}$-stabilized bricks and bricks stabilized with both lime and $\mathrm{H}_{3} \mathrm{PO}_{4}$ with achieved a rapid increase in the first 14 days and a slow increase afterwards. It can therefore be deduced that $\mathrm{H}_{3} \mathrm{PO}_{4}$ as a stabilizer increases the compressive strength of bricks more rapidly than lime, however, lime-stabilized bricks possessed greater strength with time than $\mathrm{H}_{3} \mathrm{PO}_{4}$ stabilized bricks. The Nigerian Building and Road Research Institute recommends that the minimum compressive strength for laterite bricks should not be less than $1.60 \mathrm{~N} / \mathrm{mm}^{2}$ for cement stabilized lateritic bricks [24]. This requirement was not satisfied in any of the stabilizations, however, the compressive strength of the stabilized brick increased by approximately $75 \%, 75.4 \%$, and $86 \%$ after stabilization and 28 days curing at $4 \% \mathrm{H}_{3} \mathrm{PO}_{4}, 6 \% \mathrm{H}_{3} \mathrm{PO}_{4}$ and $5 \%$ lime, which gave compressive strength of $0.874 \mathrm{~N} / \mathrm{mm}^{2}$, $0.879 \mathrm{~N} / \mathrm{mm}^{2}$ and $0.932 \mathrm{~N} / \mathrm{mm}^{2}$ respectively.

Statistical analysis of the result using 2-way ANOVA shows that neither the curing period nor the percentage of $\mathrm{H}_{3} \mathrm{PO}_{4}$ had significant effect on the compressive strength of $\mathrm{H}_{3} \mathrm{PO}_{4}$ only stabilized bricks. However, when lime was added, both the percentage of $\mathrm{H}_{3} \mathrm{PO}_{4}$ and curing periods are significant factors affecting the compressive strength of the stabilized bricks with $p=0.039$ and $p=0.0029$, respectively.

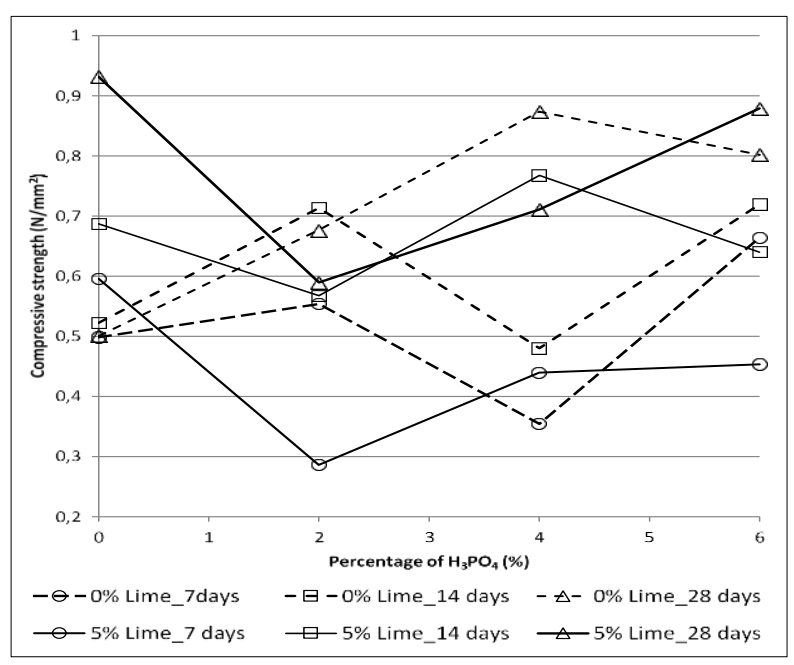

Figure 4. Compressive Strength of Stabilized Lateritic Bricks

\section{Effect of Phosphoric Acid and Lime on the Water Absorption of Stabilized Lateritic}

The water absorption test was carried out to determine the quantity of water absorbed by the brick when immersed in water for a specified time. It is used to test the durability of the brick under wet conditions. The bricks were tested at each curing period. The bricks specimens produced from laterite stabilized with $\mathrm{H}_{3} \mathrm{PO}_{4}$ and lime deteriorate after immersion in water for the specified duration of time. This can be attributed to the binding of the soil particles together brought by stabilization with $\mathrm{H}_{3} \mathrm{PO}_{4}$ which do not make the brick less permeable. The absorption of water leads to the dissociation of the bond holding the soil particles together. Limestabilized bricks exhibited a lower rate of water absorption but still crumbled. However, stabilized lateritic bricks lasted longer in water than the unstabilized lateritic bricks, it is suggested that firing the bricks could help in reducing the water absorption rate.

\section{Effect of Phosphoric Acid and Lime on the Modulus of Rupture of Stabilized Lateritic Brick}

The results of the modulus of rupture test for the bricks produced from laterite stabilized with different percentages of $\mathrm{H}_{3} \mathrm{PO}_{4}$ after 28 days curing are presented in Figure 5. According to Baldovino et al. in 2019 [9], modulus of rupture depends on the materials composition and dimensions. The results show that only the modulus of rupture at $4 \% \mathrm{H}_{3} \mathrm{PO}_{4}$ and $5 \%$ lime stabilization exceeded $0.2 \mathrm{~N} / \mathrm{mm}^{2}$. A maximum value of $0.203 \mathrm{~N} / \mathrm{mm}^{2}$ was obtained as the modulus of rupture for bricks produced from laterite stabilized with lime at 5\% stabilization. The result presented in Figure 5 shows that the control (unstabilized) brick has the lowest modulus of rupture followed by $6 \% \mathrm{H}_{3} \mathrm{PO}_{4}$ stabilized brick. It was observed that there was a small decline in the modulus of rupture values for bricks stabilized with the combination of lime and $\mathrm{H}_{3} \mathrm{PO}_{4}$ as the $\mathrm{H}_{3} \mathrm{PO}_{4}$ increased. It is therefore not advisable to stabilize by combining them when a high modulus of rupture is expected. It was recommended that the minimum value for the modulus of rupture for adobe bricks to be $0.241 \mathrm{~N} / \mathrm{mm}$ [24]. This requirement was not satisfied in any of the stabilization variations; however, after stabilizing with $4 \% \mathrm{H}_{3} \mathrm{PO}_{4}$ and $5 \%$ lime after 28 days curing, the modulus of rupture compared to the control increased by $115 \%$ and $117 \%$ respectively. This increment shows that $\mathrm{H}_{3} \mathrm{PO}_{4}$ and lime are potential stabilizers. The optimum percentages of stabilizer required is therefore $4 \% \mathrm{H}_{3} \mathrm{PO}_{4}$ and $5 \%$ lime. 


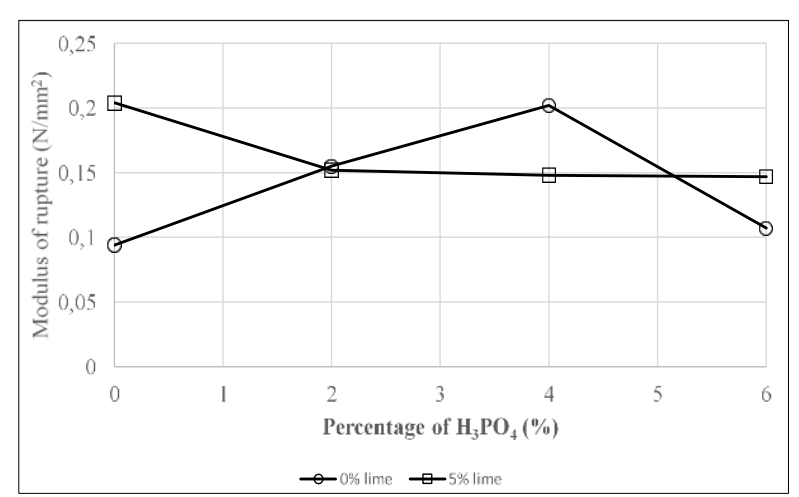

Figure 5. Modulus of Rupture Stabilized Lateritic Bricks

\section{Effect of Phosphoric Acid and Lime on the pH of Stabilized Lateritic Brick}

The $\mathrm{pH}$ of the control brick was 6.3 which is almost neutral. It was observed that an increase in the proportion of $\mathrm{H}_{3} \mathrm{PO}_{4}$ stabilization resulted in a decrease in the $\mathrm{pH}$ value down to 5.0 at $6 \% \mathrm{H}_{3} \mathrm{PO}_{4}$ (as presented in Figure 6), which implies that the bricks became more acidic. At 5\% lime stabilization, the brick's $\mathrm{pH}$ value was 9.4 and alkaline. However, the $\mathrm{pH}$ of bricks stabilized with the combination of $5 \%$ lime and varying percentage of $\mathrm{H}_{3} \mathrm{PO}_{4}$ decreased (becoming less alkaline) with increasing $\mathrm{pH}$ value as shown in Figure 6, 5\% lime still having the dominant effect. The effect of $5 \%$ lime was even more dominant on the $\mathrm{pH}$ value even when combined with $6 \% \mathrm{H}_{3} \mathrm{PO}_{4}$ because $\mathrm{H}_{3} \mathrm{PO}_{4}$ is a weak acid and of low concentration. It has been shown that $\mathrm{pH}$ has effect on the formation of cementitious compounds which can lead to improved geotechnical properties of laterites. It was shown by Ghobadi et al. [25] that shear strength parameters for clays increased considerably if the pore fluid $\mathrm{pH}$ is as high as 9 or as low as 3. Ayodele and Agbede [16] also showed that at $\mathrm{pH}$ below 7, only aluminium or/and iron phosphates cementitious compounds (and not calcium phosphates) could be formed in laterite when both calcium and phosphate ions were injected into the laterite. Both studies show that for calcium to beneficially react with laterite the $\mathrm{pH}$ must be high alkaline, infact, Glendinning and Rogers [26] specified a $\mathrm{pH}$ of greater than 12 for cementation to occur. As earlier mentioned, laterite is rich in iron and aluminium oxides [4]. The aluminium and iron oxides (as well as silicates) in the lateritic bricks in the present study were probably leached out of the laterite because of the low $\mathrm{pH}$. As such, any improvement in compressive strength might be due only to formation of aluminium and iron phosphates and not calcium phosphate within the laterite. For high $\mathrm{pH}$ (9), the calcium from lime probably reacted with silicates from the laterite. The highest compressive strength of the stabilized lateritic bricks was obtained at $5 \%$ lime stabilization at a $\mathrm{pH}$ value of 9.4 , also a comparable compressive strength was achieved at a lower $\mathrm{pH}$ value of 5.2 at $4 \%$ stabilization with $\mathrm{H}_{3} \mathrm{PO}_{4}$. The combination of lime and $\mathrm{H}_{3} \mathrm{PO}_{4}$ neutralizes the alkalinity and reduces the $\mathrm{pH}$ hence the reason for the low strength of lime and $\mathrm{H}_{3} \mathrm{PO}_{4}$ stabilized laterite bricks. It might, thus, be necessary to increase the $\mathrm{pH}$ of lime and $\mathrm{H}_{3} \mathrm{PO}_{4}$ stabilized laterite bricks by alkaline activation if calcium will beneficially react with silicate and/or phosphate ions from $\mathrm{H}_{3} \mathrm{PO}_{4}$.

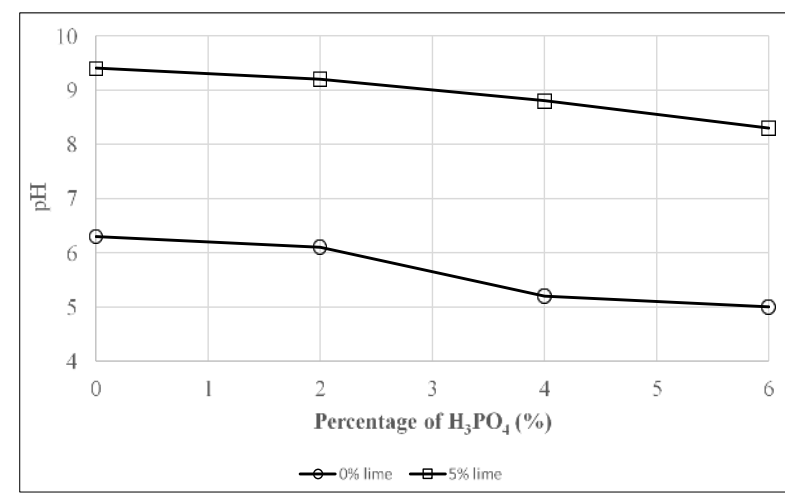

Figure 6. The $\mathrm{pH}$ of Stabilized Lateritic Brick

\section{Determination of the Optimum Percentage of Stabilizer Required}

The optimum percentage of stabilizer required is the stabilizer proportion that best enhance the engineering properties of the lateritic brick. From the tests carried out, the highest compressive strength of 0.93 $\mathrm{N} / \mathrm{mm}^{2}$ and $0.87 \mathrm{~N} / \mathrm{mm}^{2}$ was obtained at $5 \%$ lime stabilization and at $4 \% \mathrm{H}_{3} \mathrm{PO}_{4}$ stabilization respectively. The best modulus of rupture of $0.204 \mathrm{~N} / \mathrm{mm}^{2}$ and $0.202 \mathrm{~N} / \mathrm{mm}^{2}$ was also obtained at $4 \% \mathrm{H}_{3} \mathrm{PO}_{4}$ stabilization and $5 \%$ lime stabilization respectively. The best bulk and dry density result of $15.21 \mathrm{kN} / \mathrm{m}^{3}$ and $14.94 \mathrm{kN} / \mathrm{m}^{3}$ respectively was obtained at $4 \%$ $\mathrm{H}_{3} \mathrm{PO}_{4}$ stabilization, while none of the stabilizations passed the water absorption test. Also, stabilizations done by combining lime and $\mathrm{H}_{3} \mathrm{PO}_{4}$ did not prove to enhance the physical properties better than $4 \%$ $\mathrm{H}_{3} \mathrm{PO}_{4}$ or $5 \%$ lime stabilization. In conclusion, under desirable conditions the optimum percentage of $4 \%$ $1 \mathrm{M} \mathrm{H}_{3} \mathrm{PO}_{4}$ or $5 \%$ lime can be used for stabilization of lateritic hollow bricks.

\section{CONCLUSION}

Phosphoric acid and lime both improved the compressive strength of the bricks. The impact of $\mathrm{H}_{3} \mathrm{PO}_{4}$ being rapid and minimal in the first 14 days curing, while that of lime was slow but greater. At 28 days of curing, $4 \% \mathrm{H}_{3} \mathrm{PO}_{4}$ of 1 molar concentration gave a significant increase in compressive strength compared to the unstabilized control specimen. It has a value comparable to the $5 \%$ lime-stabilized specimen, which possessed the highest compressive strength. However, 
bulk density of lime stabilized specimen and specimen stabilized with the combination of lime and $\mathrm{H}_{3} \mathrm{PO}_{4}$ decreases with the passage of time while $\mathrm{H}_{3} \mathrm{PO}_{4}$ on the other hand increased. The combination of lime and $\mathrm{H}_{3} \mathrm{PO}_{4}$ as a stabilizer gave lesser compressive strength compared to lime (only) stabilized bricks, this is due to the decrease in the alkalinity, as $\mathrm{pH}$ value has been shown to have impact on the strength. Hence, alkaline activation will be necessary if $\mathrm{H}_{3} \mathrm{PO}_{4}$ and lime are to be combined when stabilizing lateritic bricks. The $4 \% \mathrm{H}_{3} \mathrm{PO}_{4}$ stabilized specimen gave the closest and optimum results from all the tests; hence it is the optimum stabilizer proportion.

\section{References}

1. Baher R., Benazzoug M., and Kenai S., Performance of Compacted Cement - Stabilized Soil. Cement and Concrete Composites, 26(7), 2004, pp. 811-820.

2. Goswami, R.K. and Singh, B., Influence of Fly Ash and Lime on Plasticity Characteristics of Residual Lateritic Soil, Proceedings of the Institution of Civil Engineers-Ground Improvement, 9(4), 2005, pp. 175-182.

3. Mitchell, J.K. and Soga, K., Fundamentals of soil behavior, Vol. 3, John Wiley \& Sons New York, 2005.

4. Gidigasu, M.D., Mode of Formation and Geotechnical Characteristics of Laterite Materials of Ghana in relation to Soil Forming Factors, Engineering Geology, 6(2), 1972, pp. 79-150.

5. Fadele, O.A. and Ata, O.J., Stabilising Potential of Sawdust Lignin based Extracts in Compressed Lateritic Bricks, Civil Engineering Dimension, 20(1), 2018, pp. 16-20.

6. Eisazadeh, A., Kassim, K.A., and Nur, H., Stabilization of Tropical Kaolin Soil with Phosphoric Acid and Lime, Natural Hazards, 61(3), 2012, pp. 931-942.

7. Muntohar, A.S., Effect of Specimen Size on the Tensile Strength Behavior of the Plastic Waste Fiber Reinforced Soil-Lime-Rice Husk Ash Mixtures, Civil Engineering Dimension, 13(2), 2011, pp. 82-89.

8. Jha, A.K. and Sivapullaiah, P.V., Mechanism of Improvement in the Strength and Volume Change Behavior of Lime Stabilized Soil, Engineering Geology, 198, 2015, pp. 53-64.

9. Baldovino, J.J.A., dos Santos Izzo, R.L., Moreira, E.B., and Rose, J.L., Optimizing the Evolution of Strength for Lime-Stabilized Rammed Soil, Journal of Rock Mechanics and Geotechnical Engineering, 11(4), 2019, pp. 882-891.

10. Olajumoke, A.M., Olonade, K.A., and Obaye, U.J., A Study of Some Engineering Properties of Coconut Shell Ash Stabilized Lateritic Bricks for
Affordable Housing, Proceedings of the Second International Conference on Innovative Technologies for Socio-Economic Transformation in Developing Countries, Пle Ife, Nigeria, September 25 - 29, 2011, pp. 89-95.

11. Wahabi, M.A., Effects of Natural Rubber Latex in Stabilizing Bricks, unpublished M.Sc. Thesis, Obafemi Awolowo University, Ile Ife, 2017.

12. Bock-Hueng, C., Ofori-Boadu, A.N., Yamb-Bell, E., and Shofoluwe, M.A., Mechanical Properties of Sustainable Adobe Bricks Stabilized with Recycled Sugarcane Fiber Waste, International Journal of Engineering Research and Application, 6, 2016, pp. 50-59.

13. Ayodele, A.L., Oketope, O.M., and Olatunde, O.S., Effect of Sawdust Ash and Eggshell Ash on Selected Engineering Properties of Lateralized Bricks for Low Cost Housing, Nigerian Journal of Technology, 38(2), 2019, 278-282.

14. Medina, J. and Guida, H.N., Stabilization of Lateritic Soils with Phosphoric Acid, Geotechnical and Geological Engineering, 13(4), 1995, pp.199216.

15. Ahmad, K.B., Taha, M.R., and Kassim, K.A., Electrokinetic Treatment on a Tropical Residual Soil, Proceedings of the Institution of Civil Engineers-Ground Improvement, 164(1), 2011, pp. 313.

16. Ayodele, A.L. and Agbede, O.A., Influence of Electrochemical Treatment on a Typical Laterite. Proceedings of the Institution of Civil EngineersGround Improvement, 171(2), 2018, pp. 103-111.

17. Falamaki, A., Shariatmadari, N., and Noorzad, A., Strength Properties of Hexametaphosphate Treated Soils, Journal of Geotechnical and Geoenvironmental Engineering, 134(8), 2008, pp. 12151218.

18. Roeselers, G. and Van Loosdrecht, M.C.M., Microbial Phytase-Induced Calcium-Phosphate Precipitation-A Potential Soil Stabilization Method, Folia Microbiologica, 55(6), 2010, pp. 621-624.

19. ASTM 67-03, Standard Test Methods for Sampling and Testing Brick and Structural Clay Tile, American Society for Testing and Materials, 2003.

20. Das B.M., Principles of Geotechnical Engineering. Thomson, India, 2006.

21. AASHTO M. 145-91, Standard Specification for Classification of Soils and Soil-Aggregate Mixtures for Highway Construction Purposes, American Association of State Highway and Transport Officials, 2008.

22. Howard, A.K., The Revised ASTM Standard on the Unified Classification System, Geotechnical Testing Journal, 7(4), 1984, pp. 216-222. 
23. Sharma, V., Vinayak, H.K., and Marwaha, B.M. Enhancing Sustainability of Rural Adobe Houses of Hills by Addition of Vernacular Fiber Reinforcement, International Journal of Sustainable Built Environment, 4(2), 2015, pp. 348-358.

24. Raheem, A.A., Bello, O.A., and Makinde, O.A., A Comparative Study of Cement and Lime Stabilized Lateritic Interlocking Blocks, The Pacific Journal of Science and Technology, 11(2), 2010, pp. 27-34.
25. Ghobadi, M.H., Abdilor, Y., and Babazadeh, R., Stabilization of Clay Soils using Lime and Effect of $\mathrm{pH}$ Variations on Shear Strength Parameters, Bulletin of Engineering Geology and the Environment,73(2), 2014, pp. 611-619.

26. Glendinning, S. and Rogers, C.D.F., Deep Stabilization using Lime. In: Glendinning, S., Rogers, C.D.F. and Dixon, N. Editors, Lime Stabilisation, Thomas Telford Publishing, London, 1996. 